\title{
The Ombudsman And Administration Of Justice In Nigeria; A Study Of Anambra State; 2010-2015
}

\author{
Osegbue, Chike, Ph.D ${ }^{1}$, \\ Department of Political Science, \\ Chukwuemeka Odumegwu Ojukwu University, Igbariam Campus \\ Anambra State, Nigeria. \\ Madubueze, Madumelu. H.C ${ }^{2}$ \\ Department of Public Administration, \\ Chukwuemeka Odumegwu Ojukwu University, Igbariam Campus \\ Anambra State, Nigeria.
}

\begin{abstract}
The issue of lack of fair hearing, unlawful dismissal of an employee and careless infringement on the fundamental rights of workers by the employers has become a serious disturbing issue. However, the institution of the Ombudsman in Nigeria which could be traced back to the 1974 Udorji Reform which recommended for its establishment in Nigeria was primarily to address that issue. This study therefore, examined the Ombudsman from 2010-2015, with the view to ascertaining how the Ombudsman has helped in ensuring the fundamental human rights of workers; whether or not, the undue government's interference impedes the performance of the Ombudsman especially in Anambra State. To achieve that objective, two research questions and hypotheses were raised. Structural Functionalism theory was used to guide the study. It made use of descriptive survey design with a study population of 69. It used a 5 point Likert scale structured questionnaire to elicit information from the respondents and the chi-square statistical tool to analyze the hypotheses. The study found that; - the Ombudsman in Nigeria especially in Anambra State has failed to enforce the fundamental human rights of workers in Nigeria; - the undue interference of the government also hindered the effective performance of the Ombudsman in Nigeria especially in Anambra State. We recommended thus, amongst others for a zero tolerance of governments' interference in the administration of Ombudsman, and that the Ombudsman should either be scrapped, or be made to be truly a watchdog over the administrative rascality being meted on workers in Nigeria especially in Anambra State. The system should be to Civil Service, what EFCC is to the Banking Sector in Nigeria.
\end{abstract}

\section{INTRODUCTION}

The Public Complaints Commission is better known all over the world as the Ombudsman. The Ombudsman is known and performed by various agencies all over the world (Wikkipedia, 2010). In United Kingdom they are known as "Parliamentary Commissioner for Administration (PCA). The Ombudsman in U.K is attached to the Parliament while there are also various other Ombudsman services in the United Kingdom, which are specific for each industry or areas of influence.

The history of the Ombudsman can be divided into three main periods. First around 1809 in an era of authoritarian monarchy. It developed as a check on executive power and incidentally it developed within the executive itself. The kings of Sweden had established it to ensure that their administration would vigorously respect and implement their laws. Ombudsmen are therefore public officers set up to strengthen the authority of the executive over the other powers. Secondly, the regimes became more parliamentary, the office was towards the second half of ninetieth century, redesigned and moved away from the sphere of the executive and became the instruments of the parliament to monitor and control the executive. Today, it is still an essential element in the Swedish theory of "constitutional" control. Thirdly, by the twentieth century, it acquired its relative autonomy and has now evolved into the citizen's instrument. Posing as the 'defender of civil rights against the arbitrariness of bureaucracy, it is no longer confined to the horizontal relationship between authorities but is also part of the vertical control of the state by citizens. As such, it combines the two basic dimensions of accountability in democratic systems (Przwouski, Stakes, and Monin, 1999).

The institution of the Ombudsman spread in the second half of the twentieth century well beyond Sweden. The Swedish model was copied in Norway, Finland, Denmark, and by the common wealth countries in the early 1960s. Over the years, the institution of the Ombudsman has grown and become more specialized and 
politicized. While being appointed by the parliament, they still try to maintain their independence, and their very easy access, point and theoretical history ears without necessary bureaucratic controls has endowed the Ombudsman to the ordinary man (Ishaq, 2011).

In Nigeria, prior to the report of the Public Service Review which was set up by the federal military government to look into the conditions of service of public workers in the federation (Udorji report, 1974), there were recommendations for the institution of a public Ombudsman in Nigeria. Upon the assumption of office as military head of state General MohammedBuhari in 1975 constituted a team to study the institution of Ombudsman in other countries with a view to setting up a peculiar Ombudsman system in Nigeria. The team's report led to the promulgation of the Public Complaints Commission Decree (now Act). The Commission consists of a Chief Commissioner and Twelve other Commissioners appointed by the Supreme Military Council, and also responsible to the council. The Commission has power to initiate investigation on its own or upon complaint on administrative action by federal or state agencies, statutory corporations, local government authorities and public institutions and companies whether in the public or private sector and officials therefore. The law was amended in 1979, by virtue of Public Complaints Commission (Amendment) Decree 21, it made some amendments to the Public Complaints Commission Decree 31 of 1975, and it inter alia conferred immunity from legal process on the Public Complaints Commissions in the performance of their official duties. Generally, the Ombudsman is a state official appointed to provide a check on government activity in the interests of the citizens and to oversee the investigation of complaints of improper government activity in the interests of the citizen. There is an acknowledgement that Nigerian citizens were once generally oppressed and victimized by the administrative powers of the government. There is a need for intervention by a supposedly neutral voice or "history ears" for the benefit of the citizens who may have a complaint against the government (Kunle, 2012).

\subsection{Statement of the Problem}

Apart from a history of individual case studies of countries on their own instituting the portfolio of the ombudsman into their public sector practice in Africa, a wholesome approach to building an alternative mechanism for protecting the ordinary citizens against powerful state bureaucracies have not become popular. National governments as well as some international organizations have started creating anti-corruption agencies and ethical bodies with large sums of money committed into the projects to bring about good governance and good ethical practices in Africa's public institutions. Examples of these bodies are the United Nations Development Programme (UNDP), World Bank, the Commonwealth, and the African Association for Public Administration and Management, amongst others. What comes from these sharing of opinions between state organs and international agencies is the fact that there is the need for the institution of the ombudsman to be strengthened throughout Africa. The situation before now has been very pitiable. This is because; the institution of the ombudsman has been non-existent in many countries in Africa (Mukoro, 2013).

In support of that, Ademolekun (2010) summarized the whole idea when he said; The number of S.S.A. (Sub -Sahara Africa) countries with ombudsman institutions increased from six (Tanzania, Ghana, Zambia, Sudan, Nigeria and Zimbabwe) in the late 1980's to about a dozen in 1995 with Malawi, Namibia, Senegal, and South Africa among the newcomers.

According to him, the performance of the ombudsman varies significantly amongst the countries that have been caught in the bug in Africa. But in each of the cases, the existence of the office of the ombudsman reflects an affirmation of a commitment to assisting citizens who seek redress against maladministration to get some reasonable amount of solution. This sends a message to public officials in Africa on the need to treat citizens with fairness and impartiality.

A critical look at the situation shows that several countries in Africa have now realized the need to adopt the ombudsman plans and anticorruption institutions in their bureaucracies. The big question is, despite these measures, has corruption amongst public officers in Nigeria vis-à-vis Africa been really tackled? One fact however remains very fundamental, and that is that these erected institutions for redress seeking such as the Ombudsman, have not succeeded in raising the level of accountability and good governance in Nigeria (Olowu, 2002).Also, Akpomuvire (2013), observed that, the Nigerian system whether in governance or through the operations of the public service, still shows signs of defects. This is because, not only is there a wide gap between the government and the people, leadership itself indulges in flagrant disregard for the rule of law and the abuse of power. To him, the alienation of state from society and the perception of the state as a hostile force, reasonably leads to a lost of faith in the Ombudsman system.

Again, Osakede\&Ijimakinwa (2014) explained that although the Ombudsman system was set up with very good intentions so to meet up with its stipulated functions, the government interference in the operations and the activities of the Ombudsman has remained a herculean task for the system to thrive. To them, the Ombudsman in Nigeria cannot entirely said to be doing its job as it has gradually been taken over by the governments influence. Nevertheless, the positions of scholars from related literatures theoretically $\mathrm{x}$-rayed the 
formations, functions as well as the defects of the Ombudsman system in Nigeria even in some African countries. Little or no attention has been paid to empirically examine the activities of the Ombudsman as specifically regards to administrative injustices in Nigeria. The need for such study thus, is exigent owing to incessant agitations of the Nigeria populace over the increasing rate of ills, ineptitudes, and corrupt practices inherent in Nigeria's public and civil service today.

\subsection{Objectives of the Study}

The broad objective of this study is to examine the role of Ombudsman in addressing administrative injustice in Nigeria using the Public Complaints Commission as a case study. The specific objectives include;

1.) To determine whether the public complaints commission has been able to redress cases of violation of fundamental human rights in Nigeriaespecially in Anambra State between 2010-2015.

2.) To ascertain whether undue government interference militate against, the ability of the Ombudsman system to ensure administration of justice in Nigeriaespecially in Anambra State between 2010-2015.

\subsection{Research Questions}

The following questions were raised to guide the study;

1.) Has the Public Complaints Commission been able to redress cases of violation of fundamental human rights of in Anambra State; 2010-2015?

2.) Does undue government interference militate against the ability of the Ombudsman system to foster administration of justice in Anambra State; 2010-2015?

\subsection{Research Hypotheses}

The following hypotheses were formulated to validate the research objectives and questions

1.) Ho: The public complaints commission has not been able to redress cases of violation of fundamental human rights in Anambra State; 2010-2015.

Hi: The public complaints commission has been able to redress cases of violation of fundamental human rights in Anambra State; 2010-2015.

2.) Ho: Undue government interference does not militate against, the ability of the Ombudsman system to foster administration of justice in Anambra State; 2010-2015.

Hi: Undue government interference militates against, the ability of the Ombudsman system to foster administration of justice in Anambra State; 2010-2015.

\subsubsection{The concept of the Ombudsman}

\section{REVIEW OF RELATED LITERATURE} According to Andren (1962) in Ezeani (2005);

The ombudsman is a law officer, appointed by a national parliament for the task of supervising the activities of certain categories of public service and of public authorities. His main concern is with the rights and liberties of the citizens. The supervision of the activities under his control has, on the whole, the observance of the laws as its primary objective, not the general suitability of decisions.

Similarly, Nigro and Nigro (1973) defined an Ombudsman as an officer of the parliament who investigates complaints from citizens that they have been unfairly dealt with by government department, and who if he finds that the complaint is justified seeks a remedy.

Again, Ezeani (2005) sees Ombudsman as an official appointed by the National Assembly or Government (as the case may be), and charged with the responsibility of protecting the citizens from the arbitrary and oppressive exercise of the executive powers of government.

On the other hands, Sultana (2007) sees the ombudsman as an institution established under the constitution or by the legislature that receives and investigates complaints reported by individual citizens against any government and institution and recommend corrective actions, an ombudsman is an office provided for by the constitution or by an action of the legislature or parliament and headed by an independent, high-level public official who is responsible to the legislature or parliament, who receives complaints from aggrieved persons against government agencies, officials, an employer or who acts on his motion, and who has the power to investigate, recommend corrective action and issue reports (Haller, 1998; Sapers\& Zinger, 2010).

Chijioke (2009) in Osakede (2014) argue that the ombudsman is a novel institution of the government which is vested with the responsibility to defend and uphold the rights of the citizens in the light of how they have been 
treated by government officials, to investigate these complaints and, where it finds them justified, propose remedial action (Birkinshaw, 1994). When remedial action is not implemented by the concerned establishment, it can publicize the case and report on it to parliament. Basically, ombudsmen are inquisitorial, not adversarial. Ombudsman can examine and interview witness and use professional experts where appropriate. The procedure for investigations can be tailored to the circumstances of the cases (British \& Irish ombudsman Association, 2009).

From the forgoing, one can simply define the ombudsman thus as an institutionalized watch-dog over the activities and modus operandi of the government and the governed. It is therefore important to note that the ombudsman have dual roles. On one hand, they provide redress for individual grievances, while on the other hand they are concerned with the improvement of service delivery standard. In effect, an ombudsman is not just an agent of redress, but also has a quality control function. By investigating individual cases, ombudsman may highlight weaknesses in practices, rules and attitudes.

Unearthing these weaknesses is of advantage to both complainants and those who have not complained. This is because the resultant improvement in the system benefits all. It is instructive to note that these two roles do not conflict and as such need not be separated (Emiola, 2002). Any institution that receives and investigates complaints is only doing half its job if its casework experience is not used to provide comprehensive feedback to the organization investigated. Such feedback could help improve the way internal complaints are dealt with. This may reduce the number of complaints that would get to the ombudsman. Feedback could also lead to improvements when investigations reveal systemic problems or failures. While the ombudsman is no doubt a novel institution, it must be stated that, it is by no means a super-administrator, vested with the power to overturn every wrong action and to provide correct answers to all the difficult questions that confront modern government (Daniel, 2013).

\subsubsection{The Concept of Administration of Justice}

Administrative justice is relatively a new concept in the field of social sciences. Scholars have not been able to articulate its meaning or conceptualization. We therefore, saw the concept from the prism of that which administrative justice is not. Thus, it can be define as arbitrary application of justice against the employees of the government. Nwachukwu (2008), in attempting to conceptualize administration of justice explained that the Ombudsman institution in every jurisdiction is a creature of statute (often constitutionally entrenched). It is set up by the government as a potent and effective office that undertakes investigations in the name of the government though not part of the government - and empowered to make recommendations for an expeditious resolutions of the complaint without any expenses for the complainant.

However, because of the caliber of the personnel usually entrusted with this office, the power usually given to the bureau, the Ombudsman has easy and unique access to government documents and officials no matter how highly placed, and through this peculiar contact can swiftly settle complaints. The Ombudsman operates largely in the area separating the individual from the executive arm of government; it is meant to hear the complaints of the individual against administrative and executive officials and agencies. It is not usually meant to review legislative and judicial acts. The Ombudsman deals with unfair administrative measures which are not suitable for judicial review as for instance when the official concerned cannot be sued or where the facts of the case cannot be proved in the courts but maybe uncovered through a non-judicial investigation (Obiagba, 1993).

Where the affected person is a man of substance, he would be in a position to help him, and if he chooses, may recourse to the legal remedies available in the regular courts for the vindication of his infringed rights and for the redress of the injustice. But the fact of the ordinary 'little man' and 'humble citizen' (whether humility of personality or humility of means) in a situation where he has to face the over-whelming bureaucrat and mindless officialdom - especially during a military regime - would appear helpless, if not for the Ombudsman. To stand in the breach between the 'small man' and the government official; and to protect the former from the 'undue influence, negligence, error of maladministration' of the latter - be he, a government official or staff of parastatals, organizations and other agencies, governments have established the office of the Ombudsman institution to succor the 'little man' in such a situation above described. He can take his cause to the Ombudsman who has the capacity to make recommendations for the redress of the administrative injustice.

Also, Osikoya(1993) sees administration of justice to be all administrative actions that have the condiments of the following;

i. Contrary to any law or regulation;

ii. mistake in law or arbitrary in the ascertainment of facts;

iii. unreasonable, unfair, oppressive or inconsistent with the general functions of administrative organs;

iv. improper in motivation or based on irrelevant considerations; 
v. unclear or inadequately explained vis-à-vis the unlawful dismissal of employees of government.

\subsubsection{The Ombudsman and Administration of Justice in Nigeria}

According to Nwachukwu (2008), historically, in 1975, the Federal Military Government led by the late Brigadier General Murtala R. Mohammed established the Ombudsman in Nigeria byDecree No. 31 dated 16th October 1975. It was designated to the Public Complaints Commission (PCC). Two reasons for this choice of name could beproffered. One was not to confuse it with the Kaduna State Public Complaints Bureau and the other was to connote the function of the commission as an establishment where the public could lodge their complaints. An appraisal of the features of Decree 31 of 1975 will now be attempted.

General Olusegun Obasanjo who succeeded the late Murtala Mohammedpromulgated a Public Complaints Commission (Amendment) Decree No. 21dated 31st May, 1979. The amendment affected three sections of the original decree. A new section 3A which placed the PCC on the schedule of pensionable lists was inserted with a view to encouraging more qualified staff to take up jobs in the Commission. A second amendment in Section 4(7) further made it mandatory for anybody required by a Commissioner to furnish any information to comply with such a requirement not later than thirty days from the receipt thereof. The last amendment in Section 8 grants Commissioner immunity fromany legal process.

According to enabling Decree the head of the Commission is called the Chief Public Complaints Commissioner. He functions at the national headquarters while his counterparts in the States are called Public Complaints Commissioners. The Chief Public Complaints Commissioner and other Commissioners are appointed by the President and are meant to be persons of proven integrity who possess such other qualifications as the President may determine. Usually, retired justices and eminent lawyers are appointed as Commissioners. A Commissioner is supposed to hold office for a term of three years in the first instance and is eligible for reappointment for a second term of three years. Thus, the maximum tenure for a Commissioner is six years.

However, Musa (1989) while contending on how a commissioner can be removed opined that, it is hoped that the Federal Government would promulgate rules defining the circumstances under which a person can be removed from office.

There should be no arbitrariness in the removal of a Commissioner; otherwise, the Public Complaints Commission cannot work fearlessly and independently. At the same time, Commissioners who perform below expectations during their first three-year term should have no justification for a second three year term reappointment”. (Musa, 1989)

Again, Nwagu (2001), maintained that compared to other Ombudsman-like institutions throughout the world, the Nigerian Public Complaints Commission ranks first among those with the most extensive formal powers. However, these formal powers mean very little unless they are effectively exercised in practice.

According to Tikara, (1980) the Ombudsman in Nigeria, like his counterparts in Sweden, should be able to conduct an investigation in certain circumstances notwithstanding the availability of legal remedy in a court of law. In his opinion, "this arrangement will only make the Ombudsman an ally to an independent judiciary". He (the Ombudsman) can supplement the rule of law with the rule of administrative good sense. He can play an important role in developing the rule of natural justice that is regrettably dwindling in Nigeria.

A cursory look at what happens in government organizations will show that in many cases, fairness or justice is the exception rather than the rule. Cases of injustice abound as many civil and public servants are denied well deserved opportunities for various informal and improper reasons which may include the fact that such staff do not come from the same place with the boss. In some other cases, the denial is based on reasons that border on victimization and sheer personal hatred (Onuzulike, 1993).

Also, Ekuma (1984) noted the power or authority vested in any office officer/administrator is usually limited by the legal or bureaucratic instrument that established the office. A good administrator operates within the limits of his powers. But very often some administrators ignore the limits of their powers and assume the position of demi-gods. Any challenge to their authority, no matter how legitimate and reasonable, is promptly resisted (justice) with intimidation or outright victimization.

However, in the bid to ensure elimination of administrative injustice, Adamolekun (1985) noted that, it was the 1979 Constitution Section 274 (5) that gave legal seal to the institution of the ombudsman that came about through the public complaint Act 1975. In Nigeria, the ombudsman operates through the office of the public complaints commission (PCC). The annual report of the PCC (2004) made it clear that it was the Udoji public service Review Commission that Recommended for the establishment of the Public complaint Commission as an independent, impartial, extra-judicial statutory body to resolve administrative grievances. The work of the Commission covers all Ministries, Departments and extra-ministerial department in all the levels of government-federal, state and local government levels. The commission is empowered to investigate complaints lodged before it on administrative action taken by;

- Any department of the federal or state government;

- Any department of any local government authority; 
- Statutory corporation or public institution set up by any government of Nigeria;

- Any company incorporated under or pursuant to the companies and Allied Matters Act whether owned by any government aforementioned or by private individuals in Nigeria or;

- $\quad$ Any officer or servant of any of the aforementioned bodies.

\subsubsection{Successes of the Ombudsman in Anambra State}

\section{Case File No. PCC/AN/2015/C.7336}

Through a letter dated $16^{\text {th }}$ June, 2015, the Public Complaints Commission Headquarters, Abuja transferred to Anambra state branch office a letter of complaints dated $15^{\text {th }}$ August, 2015 on the subject matter "Alleged Refusal to Release Bachelor of Eng. Certificate" by Miss E.P.U against the management of Nnamdi Azikiwe University, Awka.

In the letter of complaint, the petitioner, Miss E.P.U alleged that her Bachelor of Engineering statement of Result (B.Eng) was withheld after her graduation since 2011. According to her, she was a student of chemical Engineering Department and had completed all her course work and the best of her knowledge she didn't have any problem with the school management to warrant withholding of her statement of result. Explaining further, she stated that she was told she exceeded her stipulated credit load for the second semester third year because she wasn't allowed to write her exams in second semester year one academic year and after she complained to the school authorities nothing was resolved.

The Commission immediately swung into action by forwarding the letter of complaint to the Vice Chancellor, Nnamdi Azikiwe University requesting for his comments/explanation on the issue raised by the complaint or on the alternative to redress the alleged administrative wrong by releasing the petitioner's statement of result.

After two weeks when no response was received from the respondent, a reminder was issued yet no response. Consequently, a group of investigation officers from the Commission paid an on-the-spot visit to Nnamdi Azikiwe University. During the visit the investigation officer had discussion with the top management of the University, including the Vice Chancellor, the Deputy Vice Chancellor (Acad), the Registrar and the P.R.O. after a lengthy deliberation on the matter, the University management promised to look into the matter with a view to resolving it amicably and promptly too.

A month later, the Commission received an appreciation letter from the petitioner expressing her gratitude and appreciation for the way and manner the Commission handled her case. She was full of praises for the Commission for the prompt and successful resolution of her matter. A copy of the certificated was attached to her letter of appreciation to the Commission.

On this happy note, the Commission drew the curtain on the matter having been successfully resolved.

\section{CASE FILE NO. PCC/AN/2015/C.7289}

Through a letter dated $8^{\text {th }}$ October, 2013, the petitioner, Mr. J.s lodged a complaints with the Commission alleging that the he made application to the Ministry of Land, Survey and Town Planning Awka Anambra state for allocation of one plot of land for construction of residential building. His application according to him was favorably considered and allocation paper for plot 798 in the presidential layout Awka, Anambra state was given to him in May, 1999 with all the terms and conditions set out for the possession of the land duly complied by him; relevant documents, receipts of payment attached (see pg 6-7).

His problem has been that since he received the allocation the piece of land as stated above, has not been shown physically to him despite his persistent pressure to Ministry of Lands, Survey and Town Planning, Anambra state for over five (5) years. Thereafter, he was told to re-apply for alternative plot of land since the said presidential layout in which he supposed plot 798 was located in non-existent. Within the space of five (5) years, different Hon. Commissioner for lands was re-instated. Mr. J.S made several attempts in seeing them but all to no avail until December 2012 he was allowed face to face with the sitting Commissioner for lands. In view of this, the new Commissioner as he said assured him of the alternative plot of land but must pass the due new policy which states that N10,000 (Ten Thousand naira), N2,000 (Two Thousand naira only) non-refundable payment for Internally Generated Revenue (IGR) Account, and government account respectively, which he paid, yet no positive response which made him seek appeal to the Hon. Commissioner for Public Complaints Commission to come to his aid to bring back the "said allocation of a residential plot of land to him in Awka, Anambra state".

The Commission immediately swung into action by forwarding the letter of complaint to Hon. Commissioner, Ministry of Land, Survey and Town Planning Awkq, Anambra state for his comments/explanation on the issues raised by the complainant or in the alternative to readdress the alleged 
administrative wrong. After one month, when no response was received from the respondent, a reminder was issued.

After some months, Mr.J.S was full of praises for the Commission for prompt and successful resolution of his matter; he was offered an alternative plot i.e plot 416 Hall top neighborhood new Town Layout, Amawbia in consideration of his petition.

The Commission consequently closed the matter at this stage, having been successfully resolved

\section{CASE FILE NO. PCC/AN/2015/C.56}

The complaint was lodged in with the Commission in January, 2015 against one Mr.Ijomah, by the complainant. The complainant alleged that Mr.Ijomah, the landlord refuse him access to his office equipment which was locked up in December, 2014. He claimed, he did not owe the said landlord and had earlier informed him of his plan to vacate the office on the expiration of the rentage.

The Commission on receipt of the complaint invited both parties for a fact-finding interview and or a case conference, aimed at a quick and immediate resolution of the matter. The parties honored the invitation for mediation. The complainant represented his case as stated in his complaint. The respondent on his part claimed that the complainant was owing him a sum of N1,400 (One Thousand Four Hundred naira) only being 2 months PHCN bill. He also alleged that the sum of N340,000 (Three Hundred and Forty Thousand naira) only was collected from him by the complainant to assist obtaining travelling documents for his younger brother between 2011 and 2012

The complainant did not refute the respondent's claims but stated that he was not able to obtain the said travelling documents due to their inability to meet the requirements. After much deliberations and mediation of PCC, a Memorandum of Understanding (MOU) was reached and signed by the parties on $27^{\text {th }}$ April, 2015 thereof:

1. The complainant will pay the sum of N1,400 (One Thousand Four Hundred naira) only as outstanding PHCN bill to the landlord (Respondent)

2. In addition, he will pay the sum of N200,000 (Two Hundred Thousand naira) only to the respondent' brother out of N340,000 collected for failed travelling documents arrangements after removing administrative and other charges in the first week of August, 2015 and also release his international passport to PCC for collection thereafter.

3. The landlord (Respondent) on his part was to release the complainant's office equipment on the payment of outstanding N1,400 PHCN bill.

As stated in the Memorandum of Understanding, the complainant and respondent were invited for final resolution of the matter on $6^{\text {th }}$ August, 2015. The complainant confirmed the release of his office equipment as urged in the MOU. The complainant on the other hand through PCC paid the respondent's brother the sum of N200,000 only and also release his international passport as in the signed Memorandum of Understanding and confirmed receipt.The matter was successfully resolved with the above development and case file closed.

\section{CASE FILE NO. PCC/AN/2015/C.66}

Mr. N.C alleged that he acquired some shares from African Petroleum of Nigeria Plc now Forte Oil Plc in the early eighties with contact address - P.O Box 871, Okene, Kogi state. Later in 1994 the petitioner relocated to another station and he duly informed AP of Nigeria Plc to effect his new address. He followed it up by sending series of reminders to the company on the said change of address but all to no avail; hence his letter of complaint to the Commission dated $30^{\text {th }}$ January,2015 with its attachments seeking the assistance of the Commission in getting his new address effected by AP Plc so that he could have access to his dividends and bonuses.

The Commission on receipt of the complaint swung into action by first searching for the registrars incharge of AP Nigeria Plc. After thorough investigation, the Commission found that Mainstreet Registrars is incharge of African Petroleum Plc renamed Forte Oil Plc with its address at Area 3 Garki Abuja. The Commission in its usual way contacted its headquarters in Abuja for assistance in investigating same on grounds of proximity advantage with the respondent sequel to the outcome of reminders on the case to Abuja office, a reply was forwarded to the Commission on $27^{\text {th }}$ February, 2015 through Veritas Registrars Limited thereby introducing itself as the company that has taken over from Mainstreet Registrars. Accordingly, they replied that the shareholder's request for change of address for change of address has been affected and attached statement of stock position showing the new address of the petitioner clearly written on it.

The petitioner was contacted immediately on the new development on this matter and he visited the office and commended the commission for its tireless effort that brought success to the resolution of the case. The was closed formally on $28^{\text {th }}$ July, 2015 after its successful resolution by the Commission. 


\section{CASE FILE NO. PCC/AN/2015/C.6143}

The Commission through a letter dated $29^{\text {th }}$ July, 2015, received a complaint from Mr. A.F and 27 others. The said complainants were Batch B 2014/2015 Corps member who served in Awka North Local Government Area of Anambra state. They complained about non-issuance of their NYSC discharge certificates after a successful completion of the program in July, 2015.

According to the petitioners, they served meritoriously in Awka North Local Government Area of Anambra state between June, 2014 and July 2015, but unfortunately their discharge certificates were not issued to them at the end of the service year. The problem according to them was brought to the attention of the Zonal Inspector of local government to no avail. The Zonal Inspector ascertained that they had no problems with their service year thereby ruling out the possibility of an extension for the corps members, yet they were not issued their discharge certificates; Hence, their petition to Public Complaints Commission.

On receipt of the complaint, the Commission in its usual manner forwarded same with other relevant documents to the State Coordinator, National Youth Service Corps (NYSC) Anambra State for her urgent attention, explanation and / or possible redress. Less than one month after the letter was dispatched to NYSC, a letter No. NYSC/AN/91/Vol.ix/349 dated $29^{\text {th }}$ September, 2015 was received from the State Coordinator, NYSC Anambra state. In the said letter, NYSC stated that they found no certificates in their custody belonging to the purported corps members as listed in our letter. They however requested that the petitioners should through our office, the PCC furnish them with their state codes numbers to assist in determining their status with NYSC viz-a-viz the said certificates.The Commission wrote to the petitioners in line with request made by the respondent. In their response, the petitioners informed us that their discharge certificates have been released to them. They however thanked the Commission for coming to their assistance promptly. The Commission at this stage closed the matter having been successfully resolved.

Nevertheless, the above extant literatures indicated that, the issues of unlawful dismissals, denial of right to fair hearing has which orchestrated the establishment of the Ombudsman, has continued to be a reoccurring decimal till today. As efforts are being made to arrest the ugly trend, corruption, nepotism and favouritisms keeps making issues very worrisome. Below is a tabular distribution of cases received and closed by the Commission in Anambra State between 2010 to 2015.

Table 1.1 Number of Cases Received and Closed in Public Complaints Commission, Awka 20102015

\begin{tabular}{|l|l|l|l|l|l|}
\hline S/N & Year & Cases Received & $\begin{array}{l}\text { Cases } \\
\text { Closed }\end{array}$ & $\begin{array}{l}\text { Pending } \\
\text { Cases }\end{array}$ & Percentage \\
\hline 1. & 2010 & 258 & 169 & 89 & $34.50 \%$ \\
\hline 2 & 2011 & 734 & 400 & 334 & $45.50 \%$ \\
\hline 3 & 2012 & 2017 & 1819 & 198 & $9.82 \%$ \\
\hline 4 & 2013 & 6934 & 5925 & 1009 & $14.55 \%$ \\
\hline 5 & 2014 & 13176 & 10691 & 2485 & $33.54 \%$ \\
\hline 6 & 2015 & 7408 & 4419 & 2989 & $40.35 \%$ \\
\hline \multicolumn{7}{|l|}{ TOTAL } & $\mathbf{3 0 5 2 7}$ & $\mathbf{2 3 4 2 3}$ & $\mathbf{7 1 0 4}$ & \\
\hline
\end{tabular}

The table above indicated the received and closed cases in the public complaints commission, Awka as covered by the period under study. By implication, it revealed a rise and fall curve starting from 2010-2015. We noticed that as at 2010, the commission received a total of 258 cases and closed 169 with an outstanding 89 pending cases which represented $34.50 \%$ thus, in the 2015 , the commission did not meet up with half of the percentage ratio. In 2011, 2012, 2013, and 2014, the commission recorded a tremendous increase in the number of cases received and closed with pending cases in 334 with $45.50 \%$ as at 2011,198 with $9.82 \%$ as at 2012, 1009 with $14.55 \%$ as at 2013,2485 with $33.50 \%$ as at 2014 .

However, in the year 2015, we saw a drop in the number of cases received and closed which were 2989 pending cases with $40.5 \%$ as against its expected growth going by the preceding years. Reasons were given that the inherent difficulties such as recalcitrance of the respondents to petitions, government interference, which impedes justice as witnessed over time during the previous years were the causes.

\subsubsection{Government Interference in Ombudsman and Administration of Justice in Nigeria}

Nwachukwu (2008) observed that one of the fundamental problems that tend to retard the effectiveness of the Ombudsman in Nigeria relates to the occurrence of some specific complaints year after year. The obvious conclusion here is that effective remedial steps were never taken. It was like a case of treating the symptoms of an ailment without curing the actual disease. Thus, for example the West African Examination Council (WAEC) featured annually among the institutions against which numerous complaints are lodged. Unless some radical 
changes or some kind of administrative reforms are introduced into the methods of operation of such organizations, the full effective implementation of the Commission's recommendations cannot be guaranteed (Abudulahi, 1985)To Obasi (2001) Many have opined that to fully realize the lofty ideals of the Ombudsman, and to reduce, if not eliminate inefficiency and administrative injustice in the public and private sectors, and also to help provide adequate relief to the aggrieved citizens, there has to be an effective power base for the Commission by expanding its functions to include sanction power which undeniably has been the bane for its success thus far.

Similarly, Osakede (2014) while writing on "the role of ombudsman as a means of citizen redress in Nigeria" found that the Ombudsman activities are not totally independent of government interference. This indicates that government interference has degree in the activities of the commission, which in turn affects the performance of the system.

Also, Ayo and Anthony (2011), noted that the ombudsman system is incapacitated in the performance of its role by the following barriers:

(a) The ombudsman lacks the punitive power of enforcement of its decisions. This is particularly so in Nigeria of the third schedule of the 1999 constitution which confer in the PCC the power to compel the attendance of any person brought before it. This is a serious problem in the sense that the administrators could not be punished by the ombudsman. This makes the ombudsman more of an adviser than a buffer to administrative injustice.

(b) Lack of total independence from the government, to a larger extent can be a barrier. The fact that they are appointed by the government (e.g. in Nigeria) is a shortcoming

(c) Which can indirectly make them vulnerable to the wishes of the government that select them?

(d) The ombudsman cannot order a decision to be quashed. This to a certain extent negates the effectiveness of the system, because it makes the ombudsman decision vulnerable to the wishes of the bureaucrats affected, whether the bureaucrats' fear or respect the ombudsman's office.

(e) Illiteracy is another barrier to the effectiveness of the ombudsman (PCC) in the developing nations (e.g. Nigeria). Unless there are thorough and effective enlightenment programmes, this system can hardly claim to be a defender of the illiterate citizens.

\subsection{THEORETICAL FRAMEWORK}

\section{Structural-Functional Theory}

The term functional analysis and structural analysis have been applied to a great variety of approaches (Cancian, 19ó8; Merton, 1968). With their broad use in the social sciences has come discussion of the appropriateness of the use of structure and function and the type of analysis associated with the concepts (Levy, 1968). The functional approach is used more often than any other method in the study of Western political science (Susser 1992). The professional literature is full of references to the "functions" of political systems and to the relation between structure and function. Sometimes the terms are used without a clear understanding of the meaning of the functionalist position, more as linguistic fashion.

However, it is important to note that, although structural functionalism predated systems theory it still presupposes a "systems" view of the political world. Similarities link functionalism to systems analysis. Susser (1992) writes that both focuses on input - output analysis, both see political systems as striving for homeostasis or equilibrium, and both consider feedback in their analysis. Yet functionalism is significantly different.

Again, Fisher (2010) noted that Structural functionalism traces its beginnings back to the ancient Greeks and the writings of Aristotle (Susser, 1992). However, functionalism became important when Darwin's evolutionary theories began to influence thinking about human behaviour Darwin conceived of the idea of survival in functional terms. Each function was important to the survival of the whole system. Systems that could not adapt their functions ceased to exists. Other students of human behaviour borrowed these ideas, applying them to social affairs. Thus, social Darwinism imposed these same functionalists' categories into social analysis. Social Darwinists claimed that society benefited from unrestrained competition between units, that functional adaptability was required for survival, and that attempts to protect the weak hampered the functioning of society as a whole. These ideas first influenced anthropology and then sociology. Implicitly through the works of Emile Durkheim and explicitly through Parsons (1951), Merton (1968), and Almond \& Coleman, (1960) "Introduction to Politics of Developing Areas" all made these ideas became central to the social sciences and applied functionalist ideas to politics and administration.

Ibietan\&Folarin (2013) observed that the thrust of this theory by Almond (2000) is that government or states perform functions (maintenance of law and order, education, health services, defence, foreign and diplomatic services and so on) through certain institutions, agencies or organs of government which can be termed as 
structure. Almond (2000) posits that within the political system, six types of political/administrative structures are discernible, namely:

$>$ political parties;

$>$ interest groups;

$>$ legislature;

$>$ executive;

$>$ bureaucracies and

$>$ courts.

In order to implement governmental activities, there are specialized agencies or structure like the legislature, executive and judiciary performing functions which enables government to formulate, implement or enforce its policies. The policies are the goals of government while the agencies/structure provides the means.

This theory as an approach to the study of politics and administration has been described as being conservative in methodology, in view of its strong bias for status-quo, since it describes a set of institutions at a particular time. However, as a model in administration, it attempts to provide historical variation of governments or political regimes at different times and makes for precision and comprehension of administrative institutions.

\subsubsection{Application of the Theory to Study}

As an illustration of the above indicates, the Ombudsman vis-à-vis the Public Complaints Commission is amongst those specialized agencies of government in Nigeria, that are saddled with the responsibility of ensuring that government policies are duly implemented. This theory became very apt to the study because, in its applicability in respect to available extant literatures, it created room for the inherent difficulties in the practicability of government policies.

For instance, according to Ibietan\&Folarin (2013) noted that the temptation in keeping status quo in respect to structures and functions, may arise in thinking that if one understands how such structures work in a country, the insight can be applied to others, however, this is not always the case. For details see Almond G. A. et al (eds) (2000:39-42).Importantly, Structural-Functional theory gives a clearer guide as to a proper examination of how the Ombudsman uses its mechanisms to ensuring that government goals are attained by providing the means.

\subsection{GAP IN LITERATURE}

From the available literatures, it was glaringly evident that, most extant literatures has dwelled majorly on the theoretical implications of the Ombudsman (Public Complaints Commission) in Nigeria and even on its comparative capacity in Africa as an empirical study that examined the agency in relation to the extent they have helped in fostering administrative justice in Nigeria especially in Anambra State was none existent. The study therefore would bridge that gap.For instance, Ezeani (2000) observed that, the public complaints commission in Nigeria has to some extent acted as a watchdog against injustice by ensuring that fundamental human rights of the citizens are respected. To him, the existence of the Ombudsman constantly reminds the public officials of what the law requires.Also, Akpomuvire (n.d) on the other hand traced comparatively, the overall practicability of the Ombudsman in Tanzania, Zambia, Lesotho, Sierra Leone, Gambia, Ghana and Nigeria, and discovered that, many countries in Africa have all along been confronted with serious cases of unethical behavior as a result of which the public has been losing faith in public servants and politicians.

Similarly, Kunle (2012) critically examined the statutory provisions on the Public Complaint Commission. He however observed that, in Nigeria, the use of administrative power by officers of government and their institutions to oppress, victimize and discriminate against the citizenry is quite common and rampant. Again, Ayopeju\&Oyewale (2011) simply assessed the cases of Ombudsman (PCC) as a tool of accountability in Ondo State, Nigeria and noted that, government intervenes in the affairs of the commission to some extent; therefore not totally independence of the government control.

\subsection{Research Design}

\section{METHODOLOGY}

This is essentially a descriptive survey research design. The survey research design is one in which a group of people or items is studied by collecting and analyzing data from only a few people or items considered to be representative of the entire group. In other words, only a part of the population is studied, and findings from this are expected to be generalized to the entire population (Nworgu, 1991). Similarly, McBurney (1994) defines the survey research as a process of assessing public opinion or individual characteristics by the use of questionnaire and sampling methodsHere the researcher infers information about the study population based on the responses of a sample drawn from the study population. A structured questionnaire was therefore the main instrument adopted for data collection. The descriptive research method was also used and the aim of the 
descriptive analysis was to create an understanding on the nature of ombudsman and how it has fared on areas of injustices meted on the citizens.

\subsection{Area of Study}

The study centred on the Nigeria's Ombudsman which historically moved to the West African coast when Nigeria embraced the idea with the establishment of Public Complaints Commission. (The Nigeria version of the International Ombudsman) on the recommendation of the report of the public service review panel which was set-up by the General Yakubu Gowon led Federal Military Government to look into the conditions of service of all public workers in the Federation.The report which became known as the Udoji Report legally came into existence via Decree No. 31 of 16th October, 1975 during Murtala/Obasanjo regime and was amended by Decree No. 21 of 1979.It was later entrenched in the 1979 constitution and encoded as an Act of the National Assembly in CAP 37, Laws of Federation of Nigeria, 1990. It is now encapsulated in CAP, FFN, 2004.

At the global level, well over 100 countries in all the 6 continents now have the offices of the Ombudsman which include 30 national offices on the continent of Africa alone.The Commission is headed by a Chief Commissioner, other State Commissioners (political heads), Directors and other supporting staff (technocrats). The National Headquarters is located at Plot No. 424, AguiyiIronsi Way, Maitama, Abuja.The Commission has its presence in all the 36 States Nationwide and the Federal Capital Territory (FTC), Abuja Office.Furthermore, there are additional 5 Area Offices in each State and Abuja, bringing the total to 185 Area Offices Nationwide. The agencies mission statement is to restore the dignity of man through the enthronement of rule of law and protection of the individual/organization against Administrative Injustice" with the mission"To promote an effective and efficient service that is responsible and responsive to the needs of the citizenry through investigation and resolution of Complaints against Federal, State, Local Government, Public Corporations and private sector organizations and their officials"

\subsection{Population of the Study}

The target population for this research include the staff of the Public Complaints Commission and the general public with the local governments under study. The essence is to have balanced responses as to what and how the Ombudsman as an agency has achieved her responsibility of addressing administrative injustice in Nigeria. A tabula representation of the population tables are presented below;

\begin{tabular}{|l|l|l|l|}
\hline S/N & Senatorial Zone & Population & Percentage \\
\hline 1. & Ihiala (Anambra South) & 87,796 & $26.1 \%$ \\
\hline 2. & Awka South (Anambra Central) & 189,049 & $56.6 \%$ \\
\hline 3. & Ayamelum (Anambra North) & 57,342 & $17.2 \%$ \\
\hline & Total & 334,187 & 100 \\
\hline
\end{tabular}

Source: National Population Commission, 2006 Census Report

3.4 Sample Size and Sampling Technique

The study used the Taro Yamene's sample formula to determine the sample size. The formula is as follows;

$$
\mathrm{n}=\frac{\mathrm{N}}{1+\mathrm{N}(\mathrm{e})^{2}}
$$

Where; $\mathbf{n}=$ the relevant population sought

$$
\begin{aligned}
& N=\text { total population } \\
& E=\text { Sampling error }
\end{aligned}
$$

The sample size was determined as follows;

$$
\begin{aligned}
& n=\frac{334187}{1+334187(0.0025)} \\
& n=\frac{334187}{1+835.4675} \\
& n=\frac{334187}{836.4675} \\
& n=400
\end{aligned}
$$




\subsection{Sampling Techniques}

The study adopted the purposeful/judgmental sampling technique. The choice for this was informed by the fact that the researcher do not intend to administer the research instrument to anybody. In other words, we were selective in terms of deciding whom we administer the research instrument to. Our major emphasis was on age and academic qualification of a respondent.

Tabular representations of the administered/distributed questionnaire are below;

\begin{tabular}{|l|l|l|l|}
\hline S/N & Local Governments \& S. Zones & Number Administered & Percentage \\
\hline 1. & Ihiala (Anambra South) & 130 & $26.1 \%$ \\
\hline 2. & Awka South (Anambra Central) & 200 & $56.6 \%$ \\
\hline 3. & Ayamelum (Anambra North) & 70 & $17.2 \%$ \\
\hline & Total & 400 & 100 \\
\hline
\end{tabular}

Field survey, 2016

\subsection{Method of Data Collection}

The study relied heavily on both primary and secondary data.

Primarily, This involved oral interviews with the Ombudsman State Office. The interview questions were aimed at eliciting relevant information concerning the subject of investigation. The use of questionnaires which was the major research instrument used in gathering data for the study which was administered to the respondents. The instrument was structured in the modified Likert fashion, on a 5 - point scale, ranging from "strongly agree" (SA), through "agree" (A), "disagree" (D) to "strongly disagree" (SD) and "undecided" (U). Subjects were then instructed to respond to their degree of agreement with the statements contained in the instrumentThe Secondary date involved the use of textbooks, journal papers, government documentations etc. The value ranking starts from 1 through 5 . The minimum value is 1 and maximum is 5. Questions were limited to expression of opinions. The questionnaire is divided into two major sections (A and B). Section A contains information on the demographic data of the respondents, with items that include the respondent's department, rank / designation, educational qualification, years of experience and sex. Section B was further divided into three (3) subsections, (I - III) with each addressing the salient objectives of the study.

\subsection{Validity and Reliability of the Test Instrument}

The questionnaire designed for the study was subjected to a validation process for face and content validity. Face and content validity have been defined by McBurney (1994:123) as following:

Face validity is the idea that a test should appear superficially to test what it is supposed to test; and

Content validity is the notion that a test should sample the range of behaviour represented by the theoretical concept being tested.

Reliability is relevant to the phenomenon under study. The draft questionnaire was prepared and sent for modification to suit the purpose. The supervisor effected some corrections and assumed to be reliable and valid.

\subsection{Methods of Data Analyses}

The data generated from the administered and returned questionnaires were collated and presented in tables according to the objectives of this study. Responses from the set of questionnaire administered to selected civil servants were analyzed using percentage responses, mean scores, standard deviations and 5 point-Likert scale. The hypotheses formulated were tested at 0.05 level of significance, using the chi-square statistical tool of analyses the Chi-Square was first discovered by Karl Pearson in 1900. It is to test used to test the null hypothesis stating that the frequency distribution of certain events observed in a sample is in consistent with a particular theoretical distribution. The response options in the instrument are weighted as shown below;

\begin{tabular}{|l|l|l|l|l|}
\hline $\begin{array}{l}\text { Strongly Agree } \\
\text { (SA) }\end{array}$ & $\begin{array}{l}\text { Agree } \\
\text { (A) }\end{array}$ & $\begin{array}{l}\text { Disagree } \\
\text { (D) }\end{array}$ & $\begin{array}{l}\text { Strongly Disagree } \\
\text { (SD) }\end{array}$ & $\begin{array}{l}\text { Undecided } \\
\text { (U) }\end{array}$ \\
\hline
\end{tabular}

*The acceptance point for the items was 2.50 and any mean below 2.50 was regarded as rejected, not prevalent and as unpopular view.

\section{DATA PRESENTATION AND ANALYSES}

Distribution of Questionnaire

A total of Four Hundred five point likert scale structured questionnaire were distributed and sent out to the respondents in order to elicit their opinion on the subject matter. Three Hundred and Twenty one of the distributed questionnaires were duly filled and collected. It therefore, became the bases for analyses. 
We used the simple percentage method to analyse the responses and chi-square statistical tool to analyse the hypotheses. The chapter is divided into sections ' $A$ ' and ' $B$ ' respectively. The section ' $A$ ' is made up of the demographic representations of the respondents while the section ' $\mathrm{B}$ ' is based on the subject matter.

\subsection{Demographic Data of the Respondents.}

Table 4.1 Ages of Respondents

\begin{tabular}{|l|l|l|}
\hline Variables & No. of Respondent & Percentage \\
\hline $18-29$ & 50 & $28.9 \%$ \\
\hline $30-45$ & 230 & $42.8 \%$ \\
\hline $46-$ above & 130 & $28.3 \%$ \\
\hline Total & 321 & 100 \\
\hline
\end{tabular}

Sources: field survey, 2016

Table 4.4 Qualification of the Respondents

\begin{tabular}{|l|l|l|}
\hline Variables & No. of Respondent & Percentage \\
\hline FSLC & 30 & $7.5 \%$ \\
\hline WASSCE & 60 & $27.7 \%$ \\
\hline OND/HND/B.Sc & 110 & $47.4 \%$ \\
\hline M.SC/PH.D & 100 & $18.5 \%$ \\
\hline TOTAL & 321 & 100 \\
\hline
\end{tabular}

Sources: field survey, 2016.

\section{Discussions on Demographic Data}

Table 4.1, contains the ages of the respondents. The table shows that 50 or $28.9 \%$ of the respondents are within the age bracket of 18-29.

According to table 4.2 , it showed that 67 or $38.7 \%$ are males while 106 or $61.3 \%$ are females. The table 4.3 indicated that 30 or $7.5 \%$ are single, 139 or $80.3 \%$ were married while only 04 or $2.3 \%$ were divorcees.

Similarly, table 4.4 shows that 13 or $7.5 \%$ had their FLSC, 48 or $27.7 \%$ has WASSCE while the OND/HND were 82 or $47.4 \%$ and B.Sc./M.Sc./Ph.D. were 32 or $18.5 \%$.

\subsection{RESPONSES FROM THE SUBJECT MATTER}

Rights of the Citizens and Adequate Redress from the Public Complaints Commission.

Table 4.2.1: $\quad$ Responses on whether the citizen's right has adequately been redressed by the PCC

\begin{tabular}{|l|l|l|}
\hline Variables & No. of Respondent & \% responses \\
\hline SA & 62 & 19.3 \\
\hline A & 54 & 16.8 \\
\hline U & 05 & 1.6 \\
\hline D & 18 & 5.6 \\
\hline SD & 182 & 56.7 \\
\hline TOTAL & 321 & 100 \\
\hline
\end{tabular}

Sources: field survey, 2016.

From the above table, it could be seen that 12 respondents, representing $17.4 \%$ strongly agreed that the rights of the citizens has adequately been redressed, $20.3 \%$ representing 14 agreed, 05 or $7.3 \%$ were undecided, 18 or $26.1 \%$ disagreed while 20 representing $29.0 \%$ strongly disagreed. Therefore, we concluded that, the citizens right has not been adequately been redressed by the ombudsman in Anambra State.

\section{The Ombudsman (Public Complaints Commission) and Pursuit of Citizens Rights}

Table 4.2.2: Responses on whether the Ombudsman has pushed for the citizen's right in Anambra State

\begin{tabular}{|l|l|l|}
\hline Variables & No. of Respondent & \% responses \\
\hline SA & 30 & 43.5 \\
\hline A & 10 & 14.5 \\
\hline U & 03 & 4.3 \\
\hline D & 20 & 29.0 \\
\hline SD & 16 & 23.2 \\
\hline
\end{tabular}




\begin{tabular}{|l|l|l|}
\hline TOTAL & 321 & 100 \\
\hline \multicolumn{2}{|c|}{ Sources: Field survey 2016.}
\end{tabular}

From the above table, it was observed that, 30 which is representing $43.5 \%$ strongly agreed that the Ombudsman has pushed for the citizens right to fair hearing in the Anambra State. 10 or 14\% agreed, 3 or $4.3 \%$ were undecided, 20 or $29.0 \%$ disagreed while 16 or $23.2 \%$ strongly disagreed. Therefore, we concluded that indeed the Ombudsman has pursued rigorously, the right to fair hearing in Anambra State.

Unduly Retrenched Workers and Performance of the Ombudsman in Anambra State

Table 4.2.3: Responses on whether the unduly retrenched workers have been reinstated as a result of PCC.

\begin{tabular}{|l|l|l|}
\hline Variables & No. of Respondent & \% responses \\
\hline SA & 60 & 13.0 \\
\hline A & 07 & 8.7 \\
\hline U & 10 & 14.5 \\
\hline D & 04 & 5.7 \\
\hline SD & 240 & 56.0 \\
\hline TOTAL & 321 & 100 \\
\hline
\end{tabular}

Sources: field survey, 2016.

From the above table, 9 or $13.0 \%$ strongly agreed that retrenched workers have been reiterated by the Ombudsman in Anambra State, 6 or $8.7 \%$ agreed, 10 or $14.5 \%$ were undecided, 4 or $5.7 \%$ disagreed while 40 or $56.0 \%$ strongly disagreed. We therefore conclude that the workers whom are victims of administrative injustices have not been reiterated into the service by the Ombudsman mechanisms.

Flagrant use of Administrative Powers and Abuse of Human Rights

Table 4.2.4: Responses on whether the flagrant use of administrative powers has become a common occurrence

\begin{tabular}{|l|l|l|}
\hline Variables & No. of Respondent & \% responses \\
\hline SA & 50 & 72.5 \\
\hline A & 05 & 7.2 \\
\hline U & 01 & 0.1 \\
\hline D & 06 & 8.7 \\
\hline SD & 04 & 5.8 \\
\hline TOTAL & 321 & 100 \\
\hline
\end{tabular}

Sources: field survey, 2016.

From the above table, it was observed that, 50 or $72.5 \%$ strongly agreed that there was indeed a flagrant abuse of administrative powers which has become a common occurrence in Anambra State. 5 or 7.2\% agreed, 01 or $0.1 \%$ were undecided, 6 or $8.7 \%$ disagreed while 4 or $5.8 \%$ strongly disagreed. Therefore we concludes that administrative powers, have been flagrantly been abused to the detriment of workers in Anambra State.

Increment of Unlawfully Dismissed Workers for the Past Five Years

Table 4.2.5: Responses on whether the number of unlawfully dismissed Workers has Increased in the past Five Years or Not

\begin{tabular}{|l|l|l|}
\hline Variables & No. of Respondent & \% responses \\
\hline SA & 250 & 72.5 \\
\hline A & 25 & 7.2 \\
\hline U & 17 & 0.1 \\
\hline D & 26 & 8.7 \\
\hline SD & 04 & 5.8 \\
\hline TOTAL & 321 & 100 \\
\hline
\end{tabular}

Sources: field survey, 2016.

From the table above, we observed that 50 respondents which is representing $72.5 \%$ strongly agreed that in the past five years, there have been increment on the number of unlawfully dismissed workers. 5 or $7.2 \%$ agreed, 01 or $0.1 \%$ were undecided, 6 or $8.7 \%$ disagreed while 4 or $5.8 \%$ strongly disagreed. We thus concluded that, unlawfully dismissed workers have increased in the last five years.

Operational Scope of Ombudsman and Curbing of Administrative Injustice in Anambra State 
Table 4.2.6: Responses on whether the latitude permitted for the Ombudsman affects negatively, the reduction of administrative injustice in Anambra State.

\begin{tabular}{|l|l|l|}
\hline Variables & No. of Respondent & \% responses \\
\hline SA & 251 & 74.0 \\
\hline A & 28 & 11.6 \\
\hline U & 02 & 2.9 \\
\hline D & 25 & 7.2 \\
\hline SD & 13 & 4.3 \\
\hline TOTAL & 321 & 100 \\
\hline
\end{tabular}

From the above table, 51 or $74.0 \%$ strongly agreed that the operational latitude given to the Ombudsman greatly affected her ability to effectively sanction offenders. 8 or $11.6 \%$ agreed, 2 or $2.9 \%$ were undecided, 5 or $7.2 \%$ disagreed while 3 or $4.3 \%$ strongly disagreed. We thus concluded that indeed that the powers conferred on the Ombudsman to a very great extent affects her performance.

\section{Improvement of the Ombudsman in Anambra State.}

Table 4.2.7: Responses on whether the Ombudsman has performed in the past five years

\begin{tabular}{|l|l|l|}
\hline Variables & No. of Respondent & \% responses \\
\hline SA & 13 & 4.3 \\
\hline A & 13 & 4.3 \\
\hline U & 24 & 5.8 \\
\hline D & 23 & 4.3 \\
\hline SD & 256 & 81.0 \\
\hline TOTAL & 321 & 100 \\
\hline
\end{tabular}

Sources: Field survey 2016.

From the above table, we observed that, 56 respondents which is representing $81.0 \%$ strongly disagreed that the Ombudsman have performed in the five years (ie 2010-2015). 3 or $4.3 \%$ disagreed, 4 or $5.8 \%$ were undecided, agreed and strongly agreed responses were 3 which is $4.3 \%$ respectively. We therefore conclude that, the Ombudsman have not actually performed in the past five years.

Government Interference and the Performance of the Ombudsman in Anambra State

Table 4.2.8: Responses on whether Government Interference Impedes the Ombudsman Performance in Anambra State

\begin{tabular}{|l|l|l|}
\hline Variables & No. of Respondent & $\%$ of Responses \\
\hline SA & 155 & 79.7 \\
\hline A & 77 & 10.1 \\
\hline U & 22 & 2.9 \\
\hline D & 23 & 4.3 \\
\hline SD & 44 & 0.1 \\
\hline TOTAL & 321 & 100 \\
\hline
\end{tabular}

Sources: Field survey 2016.

From the above table, we observed that, 55 respondents which represented $79.7 \%$ strongly agreed that government interference impedes the performance of the Ombudsman in Anambra State. 7 or $10.1 \%$ agreed, 2 or $2.9 \%$ were undecided, 3 or $4.3 \%$ disagreed, while 01 representing $0.1 \%$ strongly disagreed. We thus, concluded that indeed government interference to a great extent affects the performance of the Ombudsman.

\section{Public Sensitization and the Public Knowledge of the PCC}

Table 4.2.9:Responses on whether the Government's Failure to sensitize her Citizens on the performance of the Ombudsman affects the public knowledge of its Existence.

\begin{tabular}{|l|l|l|}
\hline Variables & No. of Respondent & \% responses \\
\hline SA & 321 & 100 \\
\hline A & 0 & 0 \\
\hline U & 0 & 0 \\
\hline D & 0 & 0 \\
\hline
\end{tabular}




\begin{tabular}{|l|l|l|}
\hline SD & 0 & 0 \\
\hline TOTAL & 321 & 100 \\
\hline
\end{tabular}

Sources: field survey 2016.

From the above table, we observed a surprising $100 \%$ strong agreement that there is a gross failure in the ability of the government to conscientise the existence of the Ombudsman in Nigeria especially in Anambra State. All other options recorded a zero responses. We therefore conclude that indeed, the government has under marketed the Ombudsman.

Annual Publications and the Activities of the Ombudsman in Anambra State

Table 4.2.10: Responses on the impact of the lack of annual publications of the PCC

\begin{tabular}{|l|l|l|}
\hline Variables & No. of Respondent & $\%$ of responses \\
\hline SA & 316 & 87.0 \\
\hline A & 04 & 5.8 \\
\hline U & 1 & 7.2 \\
\hline D & 0 & 0 \\
\hline SD & 0 & 0 \\
\hline TOTAL & 321 & 100 \\
\hline
\end{tabular}

Sources: field survey 2016.

From the above table, we observed that 60 respondents which represents $87.0 \%$ strongly agreed that lack of regular publications on the activities of the Ombudsman also undermines her performance and makes her existence more elusive. 4 or $5.8 \%$ agreed. 5 or $7.2 \%$ were undecided while disagreed and strongly disagreed recorded zero responses. We therefore concluded that lack of annual publications on the activities of the Ombudsman, undermines her performance.

\section{TEST OF HYPOTHESES ONE}

Ho: The public complaints commission has not been able to redress cases of violation of fundamental human rights in Anambra State; 2010-2015.

Hi: The public complaints commission has been able to redress cases of violation of fundamental human rights in Anambra State; 2010-2015.

This is tested with table 4.2.1

Tabular Representation of the Calculated Chi-Square

\begin{tabular}{|c|c|c|c|c|c|}
\hline Response & $\mathbf{F 0}$ & $\boldsymbol{\Sigma} \mathbf{F}$ & $\mathbf{F 0 - \Sigma F e}$ & $(\mathbf{F 0 - \Sigma F e})^{\mathbf{2}}$ & $(\mathbf{F O - \Sigma F})^{\mathbf{2}} / \boldsymbol{\varepsilon} \mathbf{F}$ \\
\hline SA & 62 & 62 & 0 & 0 & 0.00 \\
\hline A & 54 & 62 & 8 & 64 & 1.0 \\
\hline U & 05 & 62 & 57 & 3249 & 52.4 \\
\hline D & 18 & 62 & 44 & 1936 & 31.2 \\
\hline SD & 182 & 62 & 120 & 14400 & 232.2 \\
\hline Total & 321 & & & & 316.8 \\
\hline
\end{tabular}

Source: Field survey, 2016

Thus, we compare the chi-square calculated with the chi-square tabulated.

$\mathrm{X}^{2} \mathrm{tab}=\mathrm{X}^{2},(\mathrm{r}-1)(\mathrm{c}-1)$

$$
\begin{aligned}
& =X^{2} 0.05,(5-1)(5-1) \\
& =X^{2} 0.05,16=34.267
\end{aligned}
$$

\section{DECISION}

Since the calculated chi-square $\left(\mathrm{X}^{2}\right)$ value of 316.8 is greater than the table chi-square values of 34.267 at alpha level of 0.005 and degree of freedom 16 - we therefore accept the Null Hypothesis (Ho) which states that, the public complaints commission has not been able to redress cases of violation of fundamental human rights in Anambra State; 2010-2015and reject the alternate hypothesis (Hi).

\section{TEST OF HYPOTHESES TWO}

Ho: Undue government interference does not militate against, the ability of the Ombudsman system to foster administration justice in Anambra State; 2010-2015.

Hi: Undue government interference militates against, the ability of the Ombudsman system to foster administration of justice in Anambra State; 2010-2015.

Tabular Representation of the Calculated Chi-Square

\begin{tabular}{|l|c|c|c|c|c|}
\hline Response & F0 & $\Sigma F$ & F0- $\Sigma$ Fe & $(\mathbf{F 0}-\Sigma F e)^{2}$ & $(\mathbf{F O}-\Sigma F)^{2} / \varepsilon F$ \\
\hline
\end{tabular}




\begin{tabular}{|c|c|c|c|c|c|}
\hline SA & 155 & 155 & 0 & 0 & 0.00 \\
\hline A & 77 & 155 & -78 & 6084 & 39.2 \\
\hline $\mathrm{U}$ & 22 & 155 & -133 & 17689 & 114.1 \\
\hline $\mathrm{D}$ & 23 & 155 & -132 & 17424 & 112.4 \\
\hline SD & 44 & 155 & -111 & 12321 & 79.5 \\
\hline Total & 321 & & & & 345.2 \\
\hline
\end{tabular}

Source: Field survey, 2016

Thus, we compare the chi-square calculated with the chi-square tabulated.

$$
\begin{aligned}
& X^{2} \text { tab }=X^{2},(r-1)(c-1) \\
& \quad=X^{2} 0.05,(5-1)(5-1) \\
& =X^{2} 0.05,16=34.267
\end{aligned}
$$

\section{DECISION}

Since the calculated chi-square $\left(\mathrm{X}^{2}\right)$ value of 345.2 is greater than the table chi-square values of 34.267 at alpha level of 0.005 and degree of freedom 16 - we therefore accept the alternate Hypothesis (Ho) which states that, undue government interference militates against, the ability of the Ombudsman system to foster administration of justice in Anambra State; 2010-2015 and reject the Null hypothesis (Hi).

\section{Discussions on Findings}

The instrument distributed for generation of responses from the respondents tested 10 various valued questions targeted at mainly identifying the genuine deficiencies in the wheel of progress of the Ombudsman in Anambra State. From tables 1-10, we observed several key findings. To some extent, the findings were very categorical especially in table 4.2 .9 were we noticed a $100 \%$ concurrence over the inability of the government to properly get the citizens in the know of the activities of the Ombudsman. Importantly, the study also made use of oral interviews in some areas were we observed a sharp responses either in Strong Disagreement or Strong Agreement, which was to further give us a clearer perception of what the situations are especially in circumstance where they could not as a result of fear of being sacked, write same on paper. For instance, on the inability of the government to get the public in the know of the existence of the agency, we were told that, indeed the claims that the National Orientation Agency is doing their job. They informed that huge sums of money are being earmarked for the purpose but at the end they don't do it. Again, on the area of persons that have lost their jobs since 2010-2015, we were told that virtually every two months an average of 1-2 persons are being victimized in the units where they work. And even when they reports, they use administrative powers to undermine the processes of prosecution. From all indications, we noticed a near decay system being operated in the case of the Ombudsman in Nigeria especially in Anambra State.

\subsection{Summary of findings}

From the analyses done in the section four and specifically from the hypotheses tested, we found as follows; that,

1. The public complaints commission has not been able to effectively address cases of violation of fundamental human rights of public servants in the Nigerian public service.

2. Undue government interference militates against, impinges or affects the Ombudsman system from curbing administrative injustice in Nigeria.

\subsection{Conclusion and Recommendations}

The Ombudsman or the Public Complaints Commission in Nigeria especially in Anambra State was indeed set aside to address the cases of administrative injustices ranging from the areas of unlawful dismissal, irregular queries, lack of fair hearings before trials and so many other form forms injustices in the civil and public service. The fact, therefore, is the fact that most of all the apparatuses including the Ombudsman, have grossly failed in the most of the objectives it is set to achieve. For instance, in the area of flagrant use of administrative powers to victimize staff of governments, we were told in of the one of the Anambra State owned media houses that a certain Managing Director is like a demy god. He sees himself like the Executive Governor of a State. Even by mare utterance, he suspends a staff, when an attempt is made to fight back, the victim discovers that the boss has used administrative prowess to undermine the process. We therefore conclude that, the Ombudsman has failed in her primary objectives to protect and guide the Nigerian worker from administrative injustice.

We therefore recommend that;

1. On the area of the Ombudsman (i.e. Public Complaints Commission) being able to address cases of violation of fundamental human rights of public servants in Anambra State, the commission should be given more teeth to bite as we found that the law provisions is also a hindrance in the wheel of progress of the agency. The powers to diligently arrest and prosecute any offender should be given to the agency. 
2. A total zero tolerance of governments' interference in the administration of Ombudsman should be encouraged. From all indications, undue government interference constitutes over $50 \%$ of the challenges the agency is facing today. In fact, from the oral interviews over $30 \%$ of the respondents noted that hardly could one be petitioned in the agency, you don't see a politician or a government officer coming to interfere in the process. Importantly, is the fact that the Ombudsman is to civil and public servants, what EFCC is to the banking sector. As a watchdog agency, the Ombudsman should rise above primordial sentiments and see to ensuring that the rights of the Nigerian workers are protected.

\section{REFERENCES}

[1] Adamolekun, L. (2006). Politics, Bureaucracy and development in Africa, Ibadan: SpectrumBooks Ltd

[2] Ademolekun, L. and Ogunkule, E. L, (1985), Nigeria's Ombudsman system: Five years of the Public Complaints, Ibadan: Heineman

[3] Abdulahi, M. (1985), The Ombudsman and the Nigerian masses, Kano: Bond Publishing Company.

[4] Almond, G. A; Powell, G. B; Strom, K; and Dalton, R.J (eds) (2000) Comparative Politics Today - A World View. Seventh Edition. Singapore: Pearson Education.

[5] Ayo. A and Anthony O. (2011).An assessment of the cases of Ombudsman as a tool for Accountability in Nigeria.Journal of Sustainable Development in Africa 13(4):61-71.

[6] Awopeju, A. and Oyewole, A. (2011) An Assessment of the cases of Ombudsman (PCC) as a tool of accountability in Ondo State, Nigeria; Journal of Sustainable Development in Africa Vol. 13, No.4,

[7] British and Irish Ombudsman Association (BIOA) (2009), Guide to Principles of Good Governance, available http://www.bioa.orog.uk/docs

[8] Compbell, K (1997), “Access to European community official information" internationals and comparatively law quarterly 174

[9] Daniel A. (2013). A Review of the Powers and Jurisdictional Remit of the Ombudsman Institution in Botswana.Mediterranca Journal of Social Sciences. 4(13):11-18

[10] Ezeani, E.O (2005) Public Complaints Commission and Administrative Responsibility: An Appraisal in ........... Public Accountability in Nigeria: Perspective and Issues

[11] Ekuma, O. (1984), Ombudsman in emerging African States: Issues, Umuahia Sunshine Press.

[12] Emiola A. (2001), Administrative Remedies, Ogbomosho: Emiola Publishers.

[13] Haller W. (2010). The Place of the Ombudsman in the World Community, Fourth International Ombudsman Conference Papers, Canberra, Canadian Federalcorrections 15(5), 15-24.

[14] Ibietan, J andFolarin, S (2013) Conceptual and Methodological Approaches To Comparative Public Administration International Journal Of Innovative Social Sciences \& Humanities Research 1(2):49-58.

[15] Ishaq M.S (2011) “The Role of the Public Complaints Commission in Protecting Worker's

[16] Rights against Administrative Injustice and Maladministration in Nigeria", A Masters of Law Thesis. Culled from www.google.com 12/03/2016

[17] Kunle, A (2012) The Relevance of public complaints commission to Nigeria's democratic development; International Journal of Advanced Legal Studies and Governance, Vol. 3, No. 3

[18] Musa, T. (1989), The Rule of Law, Ibadan: Bumni Press

[19] Obiagba, N.C. (1993) "Why the Ombudsman Institution in theEmergent African States", Being a Paper he Presented in the Third African regional Conference of Ombudsman entitled "Search for Social Justice and Fair Play", held in Abuja between 20th - 27th October.

[20] Onuzulike, R. (1992) Administrative Justice and the Society, Paper Presented in a Seminar - The Role of Public Complaints Commission in Treating Social Injuries in Nigeria.

[21] Osiokya, A. A. (1993). “The Nigeria Ombudsman: Is he Really A Toothless Bull-Dog?” Being A Paper he presented in the Third African Regional Conference of Ombudsman, entitled Search for Social Justice and fair Play, held in Abuja between 24th $-27^{\text {th }}$ October.

[22] Osakede, K.O \&Ijimakinwa, S.O (2014) The Role of Ombudsman as a means of citizen redress in Nigeria; Review of Public Administration and Management Vol. 3, No. 6

[23] Olowu, D. (2002), "Acountability and Transparency" in L. Adamolekun (eds). Public Administration in Africa: mainissues and selected country studies (reprint). Ibadan: Spectrum books

[24] Parson. T (1951) The Social system; New York Free Press

[25] Roy W, Davies (2010)The European Ombudsman an Alternative to the European courts; Quasi - Judicial Review: JCLI

[26] Udoji, Jerome, (1974), Federal Republic of Nigeria Public Service Commission Main Report, Lagos: Government Printer.

[27] Wikipedia (2010): The Free Encyclopedia - http://en.wikipedia.org/wiki/ombusdsman. 